\title{
Interferensi Fonologis Bahasa Arab "Analisis Kontrastif Fonem Bahasa Arab Terhadap Fonem Bahasa Indonesia Pada Mahasiswa Universitas Al Azhar Bukan Jurusan Sastra Arab"
}

\author{
Thoyib I.M ${ }^{1}$, Hasanatul Hamidah ${ }^{2}$ \\ ${ }^{1,2}$ Program Studi Sastra Arab, Fakultas Sastra, Universitas Al Azhar Indonesia, Kompleks Masjid \\ Agung Al Azhar, Jl. Sisingamangaraja, Kebayoran Baru,Jakarta Selatan 12110
}

Penulis untuk Korespondensi/Email: hamidahhanif@yahoo.com

\begin{abstract}
Abstrak - Peristiwa gangguan fonologis dapat terjadi karena kontak dua bahasa. Interaksi Arab dan Indonesia memungkinkan kontak bahasa yang dapat menyebabkan pengguna bahasa asing mengalami gangguan fonologis dan gramatikal. Penelitian ini difokuskan pada gangguan fonologis pada siswa non-Arab Universitas Al-Azhar Indonesia. Tujuan dari penelitian ini adalah untuk memberikan informasi tentang gangguan fonemik pada pelajar pemula bahasa Arab. Studi ini juga memberikan manfaat bagi guru bahasa Arab di Indonesia untuk menemukan metode dan strategi pembelajaran yang sesuai. Metode deskriptif dan metode kontrasif digunakan dalam penelitian ini. Pengumpulan data dilakukan dengan menggunakan rekaman suara pada 12 siswa dari 6 fakultas dengan cara membaca fonem bahasa Arab. Berdasarkan rekaman, ditemukan 14 gangguan nada konsonan: / $\dot{g}$ / direalisasikan sebagai [g], / q / direalisasikan sebagai [k], / ś / direalisasikan sebagai [s], / c / direalisasikan sebagai [?], / $\mathbf{t}$ / disadari sebagai [ș], / ș / direalisasikan sebagai [s], / $\mathbf{x} /$ direalisasikan sebagai $[\mathrm{h}]$ dan $[\mathbf{h}] / \mathrm{h} /$ direalisasikan sebagai [h], / đ / direalisasikan sebagai [d] dan [ð], / ठ / direalisasikan sebagai [z], / $\boldsymbol{\theta}$ / direalisasikan sebagai [s], / $\dot{\mathbf{z}}$ / direalisasikan sebagai $[z]$ dan [ð], / h / direalisasikan sebagai [h]. Intervensi vokal ditemukan dalam 4 vokal: pendek / a / vokal yang direalisasikan sebagai [o], long / a: / vokal yang direalisasikan sebagai [o], / i: / disadari sebagai [i] dan / u: / disadari sebagai $[u]$. Penyimpangan yang paling sering ditemukan dalam konsonan / $\dot{\mathbf{z}}$ / direalisasikan sebagai [z] dan konsonan / $\theta$ / direalisasikan sebanyak 29,76\%. Tingkat gangguan masingmasing responden dipengaruhi oleh dua hal: durasi belajar dan frekuensi penggunaan bahasa sehari-hari.
\end{abstract}

\section{Kata Kunci - Gangguan, Konsonan, Vokal, Artikulasi}

Abstract - Phonological interference events may occur due to two-language contacts. An Arab and Indonesian interaction allows a language contact that can lead foreign language users to experience phonological and grammatical interferences. This study is focused on phonological interferences on non-Arabic students of the Al-Azhar University of Indonesia. The objective of this study is to provide information on phonemic interferences in novice Arabic learners. This study also gives merits to Arabic teachers in Indonesia to find appropriate learning methods and strategies. Descriptive method and contrastive method were employed in this study. Data collection was conducted using sound recordings on 12 students of 6 faculties by way of reading of Arabic phonemes. Based on the recordings, 14 consonant-tone interferences were found: $/ \dot{\mathrm{g}} /$ realized as $[\mathrm{g}]$, /q/ realized as $[\mathrm{k}]$, /ś/ realized as $[\mathrm{s}], / \mathrm{s} /$ realized as $[?], / \mathbf{t} /$ realized as $[\mathrm{t}], / \mathrm{z} /$ realized as $[\mathbf{s}], / \mathbf{s} /$ realized as $[\mathrm{s}], / \mathbf{x} /$ realized as $[\mathrm{h}]$ and $[\mathbf{h}] / \mathbf{h} /$ realized as $[\mathbf{h}]$, /d/ realized as $[\mathrm{d}]$

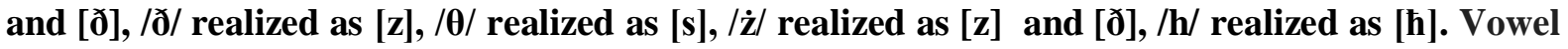
interferences were found in 4 vowels: short /a/ vowel realized as [0], long /a:/ vowel realized as [o], /i:/ realized as [i] and /u:/ realized as [u]. The most frequent deviations were found in consonant $/ \dot{z} /$ realized as $[z]$ and consonant $/ \theta /$ realized as $[s]$ as much as $29.76 \%$. The 


\section{interference level of each respondent was influenced by two things: the duration of learning and the frequency of day-to-day language use.}

\section{Keywords - Interference, Consonants, Vowels, Articulation}

\section{PENDAHULUAN}

$\mathrm{P}$ erkembangan saat ini memungkinkam setiap anggota masyarakat bahasa berinteraksi dengan anggota masyarakat bahasa lainnya dengan media internet maupun berinteraksi secara langsung. Kontak antar dua masyarakat bahasa atau lebih ini menuntut kemampuan seseorang menguasai bahasa Asing agar bisa berinteraksi. Menurut Chaer dan Agustina (2010:84) mengatakan proses penggunaan dua bahasa oleh seseorang disebut kedwibahasaan. Penggunaan bahasa secara bergantian membuat kontak antar bahasa yang digunakan seorang pengguna bahasa dapat saling mempengaruhi. Semakin sering seseorang menggunakan dua bahasa atau lebih maka semakin intensif pula kontak antar bahasa yang digunakan. Menurut Weinreich (1979) berpendapat bahwa kontak bahasa dapat terjadi karena adanya penggunaan dua bahasa atau lebih, sehingga terjadi persentuhan antara bahasa-bahasa yang memungkinkan pergantian pemakaian bahasa-bahasa yang digunakan penutur dalam konteks sosialnya. Sedangkan Chaer dan Agustina (2010: 64) berpendapat bahwa peristiwa kebahasaan yang mungkin terjadi sebagai akibat adanya peristiwa bilingualism adalah diglosia, alih kode, campur kode, interferensi, integrasi, konvergensi dan pergeseran bahasa.

Pembahasan penelitian ini lebih difokuskan pada interfersensi sebagai akibat dari bilingualism. Peristiwa interferensi terjadi pada orang Indonesia yang juga sebagai pengguna bahasa Arab. Hal tersebut tidak dapat dipungkiri karena adanya kontak antara bahasa ibu (Indonesia) dangan bahasa Arab, maupun bahasa daerah dengan bahasa Arab. Kontak bahasa Indonesia dengan bahasa Arab salah satu fakor utamanya adalah faktor agama. Sebagaimana diketahui bahwa mayoritas masyarakat Indonesia beragama Islam dan semua dasar-dasar agama Islam ditulis dalam bahasa Arab.
Interferensi adalah kekeliruan yang disebabkan adanya kecenderungan serta kebiasaan pengucapan suatu bahasa terhadap bahasa lain, mencakup pengucapan satuan bunyi, tata bahasa, kosa kata, dan makna bahkan budaya terutama dalam mempelajari bahasa kedua. Hal ini menggambarkan bahwa interferensi dapat terjadi pada semua tataran bahasa ketika seseorang melakukan komunikasi baik lisan maupun tulisan.

Peristiwa interferensi atau peristiwa digunakannya unsur-unsur bahasa lain dalam menggunakan suatu bahasa dianggap sebagai suatu kesalahan karena menyimpang dari kaidah atau aturan bahasa yang digunakan dikarenakan tidak ada padanannya dalam bahasa pertama, sehingga menimbulkan gangguan. Sesuai dengan pendapat Tobing (2012: 20-21) yang menyatakan bahwa penutur bahasa yang menggunakan dua bahasa atau lebih cenderung mencampur unsur bahasa yang satu ke dalam bahasa lain. Jika tidak terjadi dislokasi struktur pada bahasa penerima, hal itu akan memperkaya bahasa penerima tanpa merugikan bahasa sumber. Namun, apabila terjadi dislokasi struktur pada bahasa sumber, akan terjadi perusakan bahasa pada saat penutur menggunakan bahasa tersebut. Perusakan bahasa melalui lisan maupun tulisan akibat dari penggunaan bahasa secara bergantian disebut interferensi. Peristiwa interfensi biasa terjadi pada masyarakat dengan pengguna dua bahasa atau lebih. Namun, peristiwa interferensi fonologis ini akan menjadi hal yang riskan jika terjadi antara bahasa pertama (indonesia atau daerah) dengan bahasa Arab ketika membaca Al-Qur'an. AlQur'an sebagai kitab suci umat Islam merupakan landasan kehidupan umat Islam, Sehingga pembacaan yang salah akan mengakibatkan keotentikan Al-Qur'an sebagai kitab suci umat Islam akan terganggu bahakan ternodai.

Universitas Al-Azhar Indonesia sebagai universitas yang menanamkan nilai-nilai relegius menempatkan bahasa Arab sebagai 
mata kuliah umum yang wajib di ambil seluruh mahasiswa. Namun, mahasiswa bukan jurusan sastra Arab maupun mahasiswa yang tidak memiliki latar belakang pesantren dan tidak terbiasa dengan bahasa Arab menemukan banyak kesulitan. Salah satu kesulitan yang dialami oleh para pemula pembelajar bahasa Arab adalah hal pengucapan fonem-fonem Arab. Hal tersebut terjadi karena tidak semua fonem-fonem Arab memiliki padanan dalam bahasa Indonesia. Maka dari itu, penelitian ini menjadi krusial dilakukan untuk menemukan letak fonem-fonem Arab yang terjadi interferensi. Sehingga ditemukan solusi dan membenahan bahan ajar serta motode pembelajar dalam mata kuliah umum bahasa Arab untuk mahasiswa bukan jurusan sastra Arab. Penelitian ini akan membahas tentang beberapa hal yaitu:

1. Interferensi bunyi vokal dan bunyi konsonan B1 (bahasa Indonesia dan bahasaDaerah) ke B2 (bahasa Arab) mahasiswa bukan jurusan sastra Arab

2. Frekuensi bunyi vokal dan bunyi konsonan yang mengalami interferensi fonologis mahasiswa non jurusan sastra Arab?

3. Tingkat interferensi bunyi vokal dan bunyi konsonan B1 (bahasa Indonesia dan bahasaDaerah) ke B2 (bahasa Arab) mahasiswa non jurusan sastra Arab?

\section{TINJAUAN PUSTAKA}

\section{Pengertian Interferensi}

Interferensi merupakan bagian dari kajian sosiolinguistik. Istilah interferensi pertama kali dikenalkan oleh Weinrich pada tahun 1979 dalam bukunya berjudul Language in Contacts: Finding and Problems. Interferensi digunakan Weinrich untuk menyebut adanya perubahan sistem suatu bahasa sehubungan dengan adanya persentuhan bahasa tersebut dengan unsurunsur bahasa lain yang dilakukan oleh penutur yang bilingual. Interferensi mengacu pada adanya penyimpangan dalam menggunakan suatu bahasa dengan memasukkan sistem bahasa lain. Serpihan-serpihan klausa dari bahasa lain dalam suatu kalimat bahasa lain juga dapat dianggap sebagai peristiwa interferensi. Selanjutnya oleh David Crystal (2008) dalam kamusnya Dictionary of Linguistics and Phonetics mengartikan, interferensi merupakan peristiwa sebagai akibat terbawanya kebiasaan-kebiasaan ujaran bahasa ibu atau dialek dalam bahasa atau dialek kedua. Interferensi dalam bahasa dapat terjadi dalam berbagai aspek kebahasaan, seperti yang diungkapkan oleh Wayan Jendra (1991: 109) mengemukakan bahwa aspek-aspek yang menjadi bidang interferensi meliputi berbagai macam aspek kebahasaan, bidang tata bunyi (fonologi), tata bentukan kata (morfologi), tata kalimat (sintaksis), kosakata (leksikon), dan tata makna (semantik). Selanjutnya secara detail Abdul Chaer dan Agustina (2010:122126) mengidentifikasi interferensi bahasa menjadi lima macam:

a. Interferensi pada bidang fonologi yaitu perbedaan antara ujaran-ujaran (bunyi bahasa) dalam penggunaan bahasa yang digunakan oleh penutur.

b. Interferensi pada bidang morfologi Interferensi dalam bidang morfologis terdapat dalam pembentukan kata dengan afiks. Afiks-afiks suatu bahasa digunakan untuk membentuk kata dalam bahasa lain.

c. Interferensi pada bidang Sintaksis Interferensi, dalam bidang sintaksis terjadi apabila dalam bahasa terdapat struktur kalimat.

d. Interferensi pada bidang leksikal Makna leksikal adalah makna yang dimiliki atau ada pada leksem meskipun tanpa konteks apapun.

\section{Perbandingan Vokal dan Konsonan Bahasa Arab dan Indonesia}

Letmiros (1996) mengungkapkan bahwa dari perbandingan konsonan bahasa Arab dan konsonan bahasa Indonesia di atas dapat diambil beberapa kesimpulan sebagai berikut.

a. Konsonan yang terdapat dalam bahasa Indonesia dan bahasa Arab sebanyak18, yaitu /b/, /t/, /d/, /j/, /k/, /?/, /f/, /s/, /z/, /s/, $/ \mathrm{x} /, / \mathrm{h} /, / \mathrm{m} /, / \mathrm{n} /, / \mathrm{r} /, / \mathrm{q} /, / \mathrm{w} /$, dan/y/.

b. Konsonan yang hanya terdapat dalam bahasa Indonesia sebanyak 5, yaitu $/ \mathrm{p} /, / \mathrm{c} /$, $/ \mathrm{g} /, \mathrm{g} /$, dan $/ \mathrm{l} /$.

c. Konsonan yang hanya terdapat dalam bahasa Arab sebanyak 11, yaitu /t/ /, d/, /s'/,

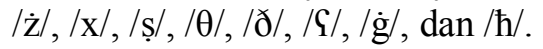

d. Konsonan /t/ dan /d/ bahasa Indonesia dan /t/ dan /d/ bahasa Arab berbeda titik artikulasi. Kedua konsonan tersebut dalam bahasa Indonesia bertitik artikulasipada alveolum, sedangkan dalam bahasa Arab bertitik artikulasi pada dental 
e. Konsonan /j/ bahasa Indonesia bertitik artikulasi pada palatum, sedangkan konsonan /j/ bahasa Arab bertitik artikulasi pada alveo-palatum. Demikian juga, titik artikulasi konsonan / / / bahasa Indonesia pada palatum, sedangkan untuk bahasa Arab pada alveo-palatum.

\section{Pengertian Analisis Kontrastif}

Menurut Richards (2010) kata kontranstif adalah menempatkan secara berhadap-hadapan dengan tujuan memperlihatkan ketidaksamaan dan membandingkan dengan cara mengamati perbedaan-perbedaan. jadi linguistik kontrastif merupakan model analisis bahasa dengan asumsi bahwa bahasa-bahasa dapat diperbandingkan secara sinkronis. Analisis bahasa dengan metode kontrastif bertujuan mengidentifikasi segi-segi perbedaan atau ketidaksamaan yang kontras (mencolok) antara dua bahasa atau lebih yang diperbandingkan, sedangkan kesamaan-kesamaannya tidak diperhatikan, karena kesamaan-kesamaan dalam bahasa merupakan hal yang biasa atau hal yang umum saja. Berdasarkan sejarah, munculnya analisis kontrastif didasari pada masalah kesulitan pengajaran bahasa Asing. Kesalahan dalam segi fonologi, semantik serta gramatikal pada pembelajaran bahasa Asing pada peserta didik karena pengaruh bahasa ibu memicu pengajar untuk melakukan perbaikan pengaran dengan melakukan analisis kontrastif pada dua bahasa tersebut. menurut Lado (1951) dalam Tajuddin (2016) menyebutkan bahwa unsur-unsuryang sama dalam bahasa ibu dan bahasa kedua sangat menunjang dalam pembelajaran bahasa kedua. Sebaliknya, unsurunsur yang berbeda dalam bahasa ibu dan bahasa kedua menimbulkan kesulitan belajar bagi peserta didik. Kesulitan belajar inilah yang menjadi salah satu sumber kesalahan berbahasa kedua. Kesulitan belajar dan kesalahan berbahasa Inggris misalnya, tidak sama pada siswa yang berbahasa ibu bahasa Indonesia dengan siswa yang berbahasa ibu bahasa Arab. Jadi, kesulitan yang dihadapi pembelajar bahasa Inggris sangat relatif tergantung dari gejala tata bahasa ibu yang dimiliki oleh peserta didik. Jadi, menurut hipotesis linguistik kontrastif adalah dengan adanya persamaanpersamaan bahasa maka proses belajar bahasa kedua akan lancar dan lebih mudah, sedangkan dengan adanya perbedaan-perbedaan bahasa maka proses belajar berjalan lambat dan terhambat.

\section{METODE PENELITIAN}

Penelitian ini menggunakan metode diskriptif serta metode perbandingan (kontrasif). metode perbandingan digunakan untuk membandingkan fonem-fonem dalam B1 dan B2. data yang digunakan berupa fonem-fonem Arab dari hasil rekaman suara responden. Responden berjumalah 12 orang dari enam fakultas dan tiap fakultas diambil sample dua orang responden. Responden bukan bersaal dari jurusan sastra Arab dan tidak pernah menyenyam pendidikan pesantren maupun sekolah formal/non formal berbasis Islam, namun mengetahui huruf hijaiyah.

Sesuai dengan tujuan penelitian yang telah dijelaskan sebelumnya, penulis akan melakukan wawancara secara langsung yang bersifat kualitatif, yaitu wawancara mahasiswa. Perekaman dilakukan secara dua kali berturutturut. Perekaman berupa pengulangan beberapa kosa kata Arab oleh responden yang dilakukan oleh peneliti yang juga dosen sastra Arab. Kosa kata yang di ucapkan merupakan kata-kata yang sudah memenuhi semua vokal dan konsonan dalam bahasa Arab.

Dalam penelitian ini analisis data yang digunakan adalah analisis kualitatif kontrastif. Paradigma kualitatif menuntut analisis data dilakukan secara terus menerus selama proses penelitian, sehingga setiap langkah saling berhubungan. Setelah berhasil mengumpulkan data primer dan sekunder, tahap selanjutnya adalah mengolah data tersebut, data yang diperolah tersebut dianalisis dengan teori kontrastif anatara BI (bahasa Arab) dengan B2 (bahasa Indonesia). Adapaun secara detail runtutan analisis penelitian ini sebagai berikut:

1. Mengumpulkan data melalui perekaman suara secara langsungke pada responden. Perekaman dilakukan dengan memberikan beberapa kosa kata bahasa Arab. Kemudian, penulis merekam proses pembacaan tersebut.

2. Menemukan jumlah interferensi yang terjadi pada proses pembacaan tersebut.

3. Menganalisis interferensi dengan teori sistem fonologi, teori analisis kontrastif vokal dan konsonan.

4. Menemukan besaran interferensi tersebut.

5. Menghitung jumlah dan frekuensi interferensi yang terjadi dan membuat irisan dari kedua sistem fonologi. 
6. Memberikan kesimpulan sehingga mendapat jawaban dari rumusan masalah.

\section{HASIL DAN PEMBAHASAN}

Penyimpangan Bunyi Konsonan dan Vokal Berdasarkan hasil rekaman responden yang berjumlah 12 orang yang membaca teks instrument berupa kosa kata bahasa Arab yang terdapat 84 bunyi fonem Arab, maka total keseluruhan data rekaman resaponden sebanyak 840 bunyi. Berdasarkan hasil rekaman tersebut dari total konsonan Arab yang berjumlah dua puluh delapan, terdapat empat belas penyimpangan konsonan dan empat penyimpangan vokal yang terjadi. Konsonan tersebut adalah $/ \mathrm{f} /, / \mathrm{g} /, / \mathrm{q} /, / \mathrm{s} /, / \mathrm{s} /$, $/ \mathrm{t} /, / \mathrm{z} /, / \mathrm{s} /, / \mathrm{x} / / \mathrm{h} /, / \mathrm{d} /, / \mathrm{d} /, / \theta /, \mid \dot{\mathrm{z}} /$, dan $/ \mathrm{h} /$. Sementara pada bunyivokal, terjadi penyimpangan pada vokal /a/ pendek dan vokal /a:/ , /i:/, dan /u:/. Secara keseluruhan penyimpangan konsonan Arab berserta titik artikulasinya dijelaskan dalam tabel berikut;

Tabel 1. Penyimpangan Konsonan Arab Beserta Titik Artikulsinya.

\begin{tabular}{|c|c|c|c|}
\hline $\begin{array}{c}\text { Konsonan } \\
\text { Asal }\end{array}$ & $\begin{array}{c}\text { Daerah } \\
\text { artikulasi }\end{array}$ & Realisasi & $\begin{array}{c}\text { Daerah } \\
\text { artikulasi }\end{array}$ \\
\hline$/ \dot{\mathrm{g}} /$ & $\begin{array}{l}\text { Velar } \\
\text { frikatif }\end{array}$ & [g] & $\begin{array}{l}\text { Velar } \\
\text { hambat }\end{array}$ \\
\hline /q/ & $\begin{array}{l}\text { Dorso } \\
\text { uvular }\end{array}$ & [k] & Velar \\
\hline /śs & $\begin{array}{l}\text { Apico } \\
\text { avelar }\end{array}$ & {$[\mathrm{s}]$} & $\begin{array}{l}\text { Apico } \\
\text { alveolar }\end{array}$ \\
\hline /G/ & Pharingeal & [?] & Laringal \\
\hline$/ \mathrm{t} /$ & $\begin{array}{l}\text { Apico } \\
\text { dental } \\
\text { alveolar }\end{array}$ & {$[\mathrm{t}]$} & $\begin{array}{l}\text { Apico } \\
\text { dental }\end{array}$ \\
\hline$/ \mathrm{h} /$ & Pharingeal & {$[\mathrm{h}]$} & Laringal \\
\hline /d/ & $\begin{array}{l}\text { Apico } \\
\text { dental } \\
\text { alveolar }\end{array}$ & $\begin{array}{l}\text { [d] } \\
\text { [ð] }\end{array}$ & $\begin{array}{l}\text { Apico } \\
\text { dental } \\
\text { alveolar } \\
\text { Interdental }\end{array}$ \\
\hline /ठ/ & Interdental & [z] & $\begin{array}{l}\text { Apico } \\
\text { alveolar }\end{array}$ \\
\hline$/ \theta /$ & interdental & {$[\mathrm{s}]$} & $\begin{array}{l}\text { Apico } \\
\text { alveolar }\end{array}$ \\
\hline$|\dot{\mathbf{z}}|$ & interdental & [z] & $\begin{array}{l}\text { Apico } \\
\text { alveolar } \\
\text { Interdental }\end{array}$ \\
\hline$/ \mathrm{h} /$ & laringal & [ћ] & Pharingeal \\
\hline$|z|$ & $\begin{array}{l}\text { Apico } \\
\text { alveolar }\end{array}$ & [ș] & $\begin{array}{l}\text { Pronto } \\
\text { palatal }\end{array}$ \\
\hline /ș/ & $\begin{array}{l}\text { Pronto } \\
\text { palatal }\end{array}$ & {$[\mathrm{s}]$} & $\begin{array}{l}\text { Apico } \\
\text { alveolar }\end{array}$ \\
\hline$/ \mathrm{x} /$ & velar & $\begin{array}{l}{[\mathrm{h}]} \\
{[\hbar]}\end{array}$ & $\begin{array}{l}\text { Laringal } \\
\text { Pharingeal }\end{array}$ \\
\hline
\end{tabular}

Dalam penyimpangan bunyi vokal, terdapat empat bunyi vokal yang mengalami interferensi vokalis, yaitu bunyi vokal /a/, /a:/, /i:/ dan /u:/. Penelitian ini membuktikan bahwa bunyi vokal /a/ yang disisipkan pada konsonan tertentu, direalisasikan menjadi bunyi vokal [0]. Bunyi vokal [o] merupakan salah bunyi vokal yang terdapat dalam bahasa Indonesia dan tidak terdapat dalam bahasa Arab. Secara teknis, bunyi vokal [0] merupakan vokal sedang belakang. Vokal ini dihasilkan dengan cara membentuk bibir dalam kondisi bundar. Sejajar dengan teknik bunyi ujar konsonan yang membentuk bibir dalam kondisi bundar, penutur bahasa Indonesia cenderung mengujarkan bunyi vokal /a/ dengan bunyi vokal [0]. Pada titik inilah interferensi vokalis terjadi. Lebih rinci lagi, realisasi bunyi vokal [0] pada kasus di atas tidak terjadi pada semua bunyi konsonan, melainkan hanya beberapa konsonan saja, yaitu bunyikonsonan $/ \dot{\mathrm{g}} /, / \dot{\mathrm{z}} /, / \mathrm{q} /$, dan $/ \mathrm{r} /$.

Penyimpangan vokal panjang terjadi pda setiap vokal pendek yang dibaca panjang. Hal tersebut dimungkinkan karena dalam sistem vokal bahasa Indonesia tidak terdapat vokal panjang, keseluruhan vokal bahasa indonesia adalah pendek. Sebernarya para informan sudah mengetahui tentang vokal panjang dalam bahasa Arab namun secara aplikasinya mereka banyak melakukan interferensi. Vokal pendek /a:/ direalisasikan dengan [o:], vokal /u:/ direalisasikan dengan [u] dan vokal /i:/ direalisasikan dengan vokal [i].

\section{Frekuensi Penyimpangan Fonem Arab}

Berdasarkan data bunyi yang diperoleh, masing-masing konsonan dan vokal yang mengalami interferensi dilihat dari segi frekuensi responden mengucapkannya. Masingmasing konsonan dan vokal berbeda frekuensi interferensinya dipengaruhi distribusi konsonan tersebut pada sebuah kata. Selanjutnya, menghitung frekuensi serta prosentase kemunculan interferensi fonologis pada tiap fonem, penulis menggunakan teknik hitung dengan cara memberikan bandingan jumlah responden yang melakukan interferensi fonologis dengan jumlah seluruh responden. Rumus menentukan prosentase menggunakan rumus yang digunakan Toyib (1994:62) sebagai berikut;

$$
\mathrm{S}=(\mathrm{jb} / \mathrm{js}) \times 100
$$




$$
\begin{array}{ll}
\mathrm{S} & : \text { Prosentase penyimpangan } \\
\mathrm{Jb} & \begin{array}{l}
\text { : bunyi yang mengalami penyimpangan } \\
\text { berjumlah } 84 \text { fonem }
\end{array} \\
\mathrm{JS} & \quad \text { : bunyi keseluruhan } \\
100 & \text { : angka tetap }
\end{array}
$$

Berdasarkan hasil rekaman fonem yang paling banyak mengalami interferensi ketika berada di awal suku kata adalah fonem $/ \theta /$. Kemudian fonem yang paling banyak mengalami penyimpangan fonologis ketika didistribusikan di tengah suku kata adalah fonem /ś/ dan /ż/. selanjutnya fonem yang mengalami interferensi terbanyak adalah fonem $/ \theta /$. Fonem yang paling banyak mengalami penyimpangan fonologis

\begin{tabular}{|c|c|c|c|c|c|}
\hline \multirow[t]{2}{*}{ Konsonan } & \multicolumn{4}{|c|}{$\begin{array}{c}\text { Frekuensi } \\
\text { Kemunculan } \\
\text { Interferensi }\end{array}$} & \multirow{2}{*}{$\begin{array}{l}\text { Prosentase } \\
\text { (Jb/js) x } \\
100\end{array}$} \\
\hline & $\bar{I}$ & II & III & Total & \\
\hline$/ \dot{\mathrm{g}} /$ & 3 & 5 & 3 & 12 & $14.28 \%$ \\
\hline /q/ & 3 & 5 & 7 & 15 & $17.86 \%$ \\
\hline |'śs & 7 & 10 & 7 & 24 & $28.57 \%$ \\
\hline /ৎ/ & 5 & 5 & 6 & 16 & $19.05 \%$ \\
\hline$/ \mathbf{t} /$ & 7 & 5 & 6 & 18 & $21.43 \%$ \\
\hline$/ \hbar /$ & 3 & 3 & 3 & 9 & $10.71 \%$ \\
\hline /d/ & 8 & 8 & 5 & 21 & $25 \%$ \\
\hline /ð/ & 6 & 7 & 6 & 17 & $20.24 \%$ \\
\hline$/ \theta /$ & 9 & 8 & 8 & 25 & $29.76 \%$ \\
\hline$|\dot{\mathbf{z}}|$ & 8 & 10 & 7 & 25 & $29.76 \%$ \\
\hline$/ \mathrm{h} /$ & - & 9 & - & 9 & $10.71 \%$ \\
\hline |z/ & - & 4 & 3 & 7 & $8.33 \%$ \\
\hline /ṣ/ & 5 & 6 & 5 & 16 & $19.05 \%$ \\
\hline$/ \mathrm{x} /$ & 5 & 4 & 3 & 12 & $14.28 \%$ \\
\hline
\end{tabular}
adalah fonem $/ \theta /$ dan $/ \dot{z} /$. Secara lebih detail disajikan dalam table berikut:

Tabel 2. Hasil Rekaman Fonem Yang Mengalami Penyimpangan Fonologis

Berdasarkana tabel tersebut dapat dijabarkan bahwa konsonan / $/ \dot{\mathrm{g}} /$ direalisasikan dengan bunyi [g] sebagai bunyi hambat velar bersuara dan bunyi [k] sebagai bunyi hambat velar bersuara. Bunyi frikatif velar bersuara $/ \dot{\mathrm{g}} /$ tidak mempunyai kesepadanan bunyi dalam sistem konsonan bahasa Indonesia sehingga prosentase penyimpangan konsonan tersebut $14.28 \%$. Sebanyak 12 informan melakukan penyimpangan sebanyak 12 kali pada konsonan $/ \dot{\mathrm{g}} /$ dan yang terbanyak adalah interferensi $/ \dot{\mathrm{g}} /$ ketika berada di tengah suku kata.

Sedangkan Konsonan /q/ direalisasikan menjadi bunyi $[\mathrm{k}]$ yang merupakan bunyi hambat velar takbersuara. Konsonan /q/ seharusnya dibunyikan hambat uvular tak beraspirasi dan tak bersuara. Kesulitan responden terhadap bunyi ini terjadi ketika fonem /q/ berada di tengah dan akhir hal ini yaitu sebanyak 7 kali.

Konsonan / $/$ / hambat velarisasi dental bersuara sering direalisasikan tanpa velarisasi,menjadi bunyi $[\mathrm{t}$ ] hambat dental takbersuara. Kasus ini sering terjadi pada bunyi konsonan bahasa Arab yang seharusnya mendapatkan velarisasi. Penyebab interferensi adalah tidak adanya bunyi /t/ pada bahasa Indonesia. Secara keseluruhan, sebanyak 18 kali penyimpangan yang dilakukan oleh responden, penyimpangan yang paling banyak terjadi pada awal suku kata.

Sementara itu, fonem $/ \dot{\mathbf{z}} /$ dengan direalisasikan fonem [z], konsonan direalisasikan menjadi bunyi [z] frikatif alveolar bersuara. Bunyi /ż/ termasuk bunyi yang sukar diucapkan karena konsonan / $\dot{\mathbf{z}} /$ adalah bunyi frikatif interdental velarisasi takbersuara yang tidak memiliki padanan dalam bahasa Indonesia. Bunyi / $\dot{\mathbf{z}} /$ merupakan hasil velarisasi bunyi $/ \theta /$ yang juga tidak memiliki padanan dalam bahasa Indonesia. Secara keseluruhan, sebanyak 25 kali penyimpangan yang terjadi pada fonem $/ \dot{\mathbf{z}} /$ dan yang paling banyak ketika fonem tersebut berada ditengah suku kata.

Kemudian, bunyi fonem $/ \mathrm{h} /$ dengan direalisasikan dengan fonem [h]. Konsonan $/ \mathrm{h} /$ direalisasikan menjadi bunyi [h], karena bagi penutur bahasaIndonesia, bunyi frikatif glotal tak bersuara [h] lebih familiar dibandingkan denganbunyi frikatif faringal bersuara pada konsonan $/ \hbar /$. Secara keseluruhan, penyimpangan pada fonem ini sebanyak 9 kali.

Sementara itu, Konsonan $/ \theta /$ direalisasikan menjadi bunyi [s] frikatif alveolar takbersuara. Bunyi / $/$ termasuk bunyi yang sukar diucapkan karena konsonan $/ \theta /$ adalah bunyi frikatif interdental bersuara yang tidak memiliki padanan dalam bahasa Indonesia. Secara keseluruhan, fonem $/ \theta /$ mengalami $25 \mathrm{kali}$ penyimpangan pengucapan. Informan kesulitan mengucapkan fonem $/ \theta /$ ketika berada di depan. Interferensi fonem ini mencapai $29.76 \%$ sama banyaknya dengan fonem $/ \dot{z} /$. 
Selanjutnya konsonan /द/ bunyi frikatif faringal bersuara sering direalisasikan sebagai bunyi vocal [a] yang dibunyikan tanpa persentuhan artikulator aktif dan artikulator pasif. Kadangkala bunyi /\&/ direalisasikan dengan bunyi hambat glotal [?] jika terdapat ditengah suku kata. Mengingat konsonan / / / merupakan bunyi frikatif faringal bersuara yang hanya terdapat pada bahasa Arab dan Ibrani, maka untuk penutur asli bahasa Indonesia, bunyi tersebut sukar untuk diucapkan. Secara keseluruhan, fonem ini mengalami interferensi sebanyak19.05\%.

Sementara itu, Konsonan /śs/ direalisasikan menjadi bunyi [s] yang merupakan bunyi frikatif alveolar takbersuara. Konsonan /śs/ merupakan bunyi frikatif velarisasi alveolar bersuara yang sulit diucapkan, mengingat dalam bahasa Indonesia bunyi hasil dari artikulasi sekunder seperti velarisasi tidak ditemukan. Secara keseluruhan, sebanyak28.57 $\%$ penyimpangan yang terjadi pada fonem ini.

Kemudian, konsonan /d/ hambat velarisasi dental bersuara direalisasikan menjadi bunyi hambat alveolar [d] dikarenakan bunyi-bunyi tersebut sering tertukar dengan konsonan/đ/ yang dibunyikan ganda, akibat dari adanya penanda geminasi. Selain itu,tertukarnya ketiga bunyi tersebut dikarenakan oleh pengucapan bunyi [d], dan /d/menggunakan cara yang sama, yakni hambat. Secara keseluruhan, sebanyak $25 \%$ penyimpangan yang terjadi pada fonem $/ \mathrm{d} /$.

Sementara itu, konsonan /ð/ direalisasikan menjadi bunyi $[\mathrm{z}]$ frikatif alveolar bersuara. Bunyi /ð/termasuk bunyi yang sukar diucapkan karena konsonan $/ ð /$ adalah bunyi frikatif interdental bersuara yang tidak memiliki padanan dalam bahasa Indonesia. Secara keseluruhan, sebanyak $20.24 \%$ penyimpangan yang terjadi padafonem /ð/.

Selanjutnya konsonan /z/ dan /h/ juga mengalami penyimpangan. Namun, penyimpangan tersebut tidak terjadi pada seluruh suku kata. Fonem /z/ direalisasikan dengan [ș] dan [j] ketika berada ditengah dan akhir. Prosentasi penyimpangan konsonan/z/ sebanyak $8.33 \%$. Sedangkan konsonan $/ \mathrm{h} /$ direalisasikan dengan konsonan [ $\hbar]$ ketika berada di tengah suku kata. Penyimpangan konsonan ini sebanyak $10.71 \%$. Kemudian fonem /x/ juga banyak mengalami penyimpangan yaitu sebanyak $14.28 \%$. Bunyi fonem $/ \mathrm{x} /$ direalisasikan dengan fonem [h] dan [ћ] . penyimpangan ini terjadi baik di awal, tengah maupun akhir suku kata. Terakhir, fonem /ș/ yang direalisasikan dengan fonem [s]. penyimpangan kondonan ini juga termasuk besar yaitu sebanyak $19.05 \%$ yang terjadi baik di awal, tengah maupun akhir suku kata.

\section{Irisan Interferensi Fonologis}

Dari dua puluh delapan konsonan bahasa Arab, terdapat sebelas konsonan yang berada di luar wilayah irisan. Artinya, konsonan tersebut merupakan konsonan yang tidak dapat diujarkan secara tepat oleh penutur bahasa Indonesia, sehingga terjadi interferensi. Konsonan tersebut adalah $/ \dot{\mathrm{g}} /, / \mathrm{s} /, / \mathbf{s} /, / \mathrm{S} /, / \mathfrak{t} /, / \mathrm{h} /$, $/ \mathrm{d} /, / \mathrm{d} /, / \theta /, / \mathrm{x} /$ dan $/ \dot{\mathrm{z}} /$. Pada dasarnya, seluruh konsonan ini tidak terdapat bunyi ujarannya pada sistem fonologis bahasa Indonesia, sehingga deteksi interferensi dapat dilakukan pada konsonan ini. Sehingga dalam irisan kesebelas konsosnan ini berada diluar irisan.

Kemudian dalam sistem fonologis bahasa Indonesia, terdapat lima konsonan yang tidak terdapat pada sistem fonologis bahasa Arab. Konsonan tersebut adalah $/ \mathrm{p} / / \mathrm{c} /, / \mathrm{g} /, / \mathrm{p} /$, dan /n/, Artinya, kelima konsonan ini tidak mungkin terdapat bahasa Arab. Selain itu, upaya lain untuk membuktikan bahwa kelima konsonan ini tidak terdapat pada sistem fonologis bahasa Arab dapat dilakukan melalui penelitian lebih lanjut yang melibatkan penutur bahasa Arab sebagai respondennya. Sedangkan fonem-fonem yang sama dalam bahasa Arab dan bahasa Indonesia terdapat 18 fonem yaitu $\mathrm{b} /, / \mathrm{t} /, / \mathrm{d} /, / \mathrm{j} /, / \mathrm{k} /, / ? /, / \mathrm{f} /, / \mathrm{s} /, / \mathrm{z} /, / \mathrm{J} /, / \mathrm{h} /, / \mathrm{m} /, / \mathrm{n} /, / \mathrm{r} /, / \mathrm{q} /, /$ $\mathrm{w} / \mathrm{dan} / \mathrm{y} /$.

Namun, walaupun terdapat dalam sistem fonetis bahasa Indonesia tapi masih juga terdapat fonem Bahasa Arab yang mengalami interferensi yaitu fonem /q/, /z/ dan $/ \mathrm{h} /$. interferensi tersebut karena perbedaan titik artikulasi konsonan tersebut dalam bahasa Arab pada titik artikulasi bahasa Indonesia.

\section{Tingkat Interferensi fonologis fonem Arab}

Pengukuran tingkat interferensi dilakukan dengan cara melihat lama belajar bahasa Arab dan juga lama penggunaan bahasa Arab. Berdasarkan 12 responden dapat di dapatkan rangkuman sebagai berikut, 
1. 2 orang responden telah mempelajari bahasa Arab sejak SD sampai SMA, namun tidak menggunakan bahasa Arab dalam percakapan.

2. 3 orang responden mempelajari dan mengetahui bahasa Arab ketika SD sampai SMP saja. Namun tidak menggunakan dalam percakapan sehari hari.

3. 5 orang tidak mempelajari bahasa Arab dalam sekolah formal namun mempergunakan dalam membaca $\mathrm{Al}$ Qur'an

4. 2 orang mempelajari bahasa Arab ketika SMA saja dan tidak menggunakan dalam percakapan sehari-hari

Berdasarkan analisis dapat ditemukan bahwa responden yang paling banyak melakukan interferensi adalah yang tidak mendapatkan pembelajaran bahasa Arab namun dapat membaca Al-qur'an. Sebanyak $13.27 \%$. Namun, dari table juga didapatkan bahwa responden yang belajar bahsa arab hanya sejak SD juga mengalami interferensi yang besar sejumlah $11.06 \%$.

Kemudian tingkat interferensi juga dapat di ukur dari banyaknya bahasa yang digunakan dalam sehari hari responden. Berdasarkan wawancara dan profil responden dapat dirangkumkan sebagai berikut,

1. 3 orang reponden mengetahui dan sering menggunakan dalam sehari-hari 3 bahasa, yaitu bahsa indonesia, bahasa Indonesia, bahasa Daerah dan Bahasa Asing (inggris)

2. 5 orang responden mengetahui dan sering menggunakan 2 bahasa dalam sehari harihari, yaitu bahasa Indonesia dan bahasa Daerah

3. Seorang responden mengetahui dan sering menggunakan 4 bahasa dalam sehari-hari, yaitu bahasa Indonesia, bahasa daerah, dan dua bahasa Asing (inggris dan jepang)

4. 3 orang responden mengetahui dan menggunakan hanya satu bahasa dalam sehari hari yaitu bahasa Indonesia.

Berdasarkan penggunaan bahasa, maka dapat disimpulkan bahwa penggunaan bahasa lebih banyak juga mempengaruhi tingkat penyimpangan fonem Arab. Responden yang menggunakan 4 bahasa mengalami penyimpangan $13.27 \%$. namun ada juga responden yang hanya menggunakan satu bahasa namun mengalami interferensi yang cukup tinggi yaitu $10.18 \%$.

\section{KESIMPULAN}

Berdasarkan hasil dari deskripsi data penelitian dapat disimpulkan bahwa interferensi terjadi karena faktor kesulitan mengucapkan fonemfonem yang tidak terdapat padanannya dalam bahasa Indonesia. Interferensi juga terjadi pada fonem-fonem yang dalam bahasa Indonesia jarang sekali penggunaannya dalam sebuah kata. Interferensi terjadi pada responden karena responden merupakan pembelajar pemula bahasa Arab sehingga masih dalam tahapan prooses belajar bahasa Arab.

\section{UCAPAN TERIMA KASIH}

KAMI UCAPAKAN TERIMA KASIH KEPADA ALLAH SWT YANG TELAH MEMBERIKAN KELANCARAN DAN KEMUDAHAN DALAM MELAKUKAN PENELITIAN DAN MENULISKAN LAPORAN. UCAPAN TERIMA KASIH JUGA PATUT KAMI SAMPAIKAN KEPADA PARA RESPONDEN, YAITU MAHASISWA DARI BERBAGAI FAKULTAS YANG TELAH MELUANGKAN WAKTUNYA DAN BERDISKUSI KETIKA PENGAMBILAN REKAMAN SUARA. KAMI SAMPAIKAN TERIMA KASIH JUGA KEPADA SMEUA PIHAK JURUSAN SASTRA ARAB YANG IKUT MEMBANTU KELANCARAN PENELITIAN INI.

\section{DAFTAR PUSTAKA}

[1] Chaer. Abdul et. al.2010. Sosiolinguistik suatu Pengantar. Rineka Cipta: Jakarta.

[2] Crystal. David, A Dictionary of Linguistic and Phonetics, Blackwell Publishing, UK, 2008

[3] Jendra I Wayan. 1991. Dasar - Dasar Sosiolinguistik. Denpasar: Ikayana

[4] Letmiros. Tesis, Fakultas Sastra, Universitas Indonesia, Indonesia, 1996. patent

[5] Nur. Tajuddin, analisis kontrastif dalam studi bahasa arab. Journal of Arabic Studies 1 (2), p64-74,2016 
[6] Richards. Jack C, Scmidt. Richard, Dictionary of Language Teaching and Applied Linguistics, Routledge, New York, 2010

[7] Tobing, Roswita Lumban. Tesis, Program Pascasarjana, Fakultas Ilmu
Budaya Universitas Gadjah Mada, Yogyakarta, 2012,Patent

[8] Weinreich. Uriel.1979. Language in Contacts: Finding and Problems.Mouton Publishe: Paris 